\title{
45
}

\section{Concurrent Engineering Applications in Mexico: two case studies}

\author{
A. Molina, E. Gomez, D. Guerra \\ Centro de Sistemas Integrados de Manufactura, \\ ITESM, Campus Monterrey, CP 64849, \\ Monterrey, N.L. Mexico \\ fax: +52 (8) 358-1209, e-mail: \\ armolina@campus.mty.itesm.mx
}

\begin{abstract}
The result of a study in the area of Concurrent Engineering in Mexican Companies is presented in this paper. This study identified the following major issues: the need to train/educate engineers in $\mathrm{CE}$ and to support design process automation, the lack of standardized product definitions and design for manufacture rules, and the necessity to introduce social-technical design concepts and cooperative design methods. From the 12 companies analyzed, two were selected to reengineer their design process in order to improve their product development processes. The process and information collected was used to develop two Computer Aided Engineering Systems to support Concurrent Engineering: Concurrent Design System for Automotive Part Dies and Integrated Development Environment of Glass Products.
\end{abstract}

\section{Keywords}

Concurrent Engineering, Assessment Tool, Process Models, Information Models, CAE System

\section{INTRODUCTION}

Mexico is playing a leading role in the Latin American manufacturing industry. The NAFTA agreement has forced Mexican companies, especially Automotive Parts Manufacturers, to implement new philosophies in order to become more competitive. The major approaches being used are: Concurrent Engineering/Simultaneous Engineering and Agile Manufacturing.

In order to support Mexican Manufacturing Companies, ITESM (Instituto Tecnológico y de Estudios Superiores de Monterrey), the largest private university 
system in Latin America, created the CSIM (Centro de Sistemas Integrados de Manufactura) with the mission to train engineers with specialized knowledge in new manufacturing paradigms, methodologies and computer tools, and to develop and transfer new technologies to Mexican Industry. A new multidisciplinary research team has been created within CSIM named GI-INCIVI (acronym in Spanish for Life Cycle Engineering Research Group). The objective of the group is to explore the following areas with a unique integrated approach in Life Cycle Research (Molina, 1996):

1. Enterprise Life Cycle which comprises the strategic management process, enterprise engineering/integration process and enterprise lifetime process.

2. Product Life Cycle that involves the product development process from its conception to its disposal.

3. Technology Life Cycle related to the technology management process to identify technologies at different stage of evolution (emerging, pacing, key and basis) to be used to support the previous life cycle processes.

This paper presents the results achieved so far at CSIM by GI-INCIVI in the area of Product Life Cycle research.

\section{PRODUCT LIFE CYCLE RESEARCH}

The projects related to Product Life Cycle were targeted to introduce and implement the concept of Concurrent Engineering in Mexican Companies. The following projects have been developed:

1. Assessment Tool for Concurrent Engineering: An assessment tool was modified and applied to 12 Mexican companies in order to identify areas of opportunity to introduce Concurrent Engineering concepts, methodologies and tools (Gomez and Molina, 1996).

2. Methodology for Re-engineering the Design Process: based on the results of our study in Mexican companies the need to create a methodology to reengineer the design process was identified. The aim of the methodology is to formalize and integrate the design process in order to standardize and improve the development of products within manufacturing companies (Gomez 1996, Guerra 1996). The methodology integrates the concepts of core processes, core competencies, strategic and technology planning in order to define the necessary learning and technical capabilities to support product development processes (Hamel and Prahalad 1990). This methodology is being extended to tackle the Enterprise Life Cycle process as well (Bernus and Nemes, 1994). 
3. Development of Computer Aided Engineering Systems for Concurrent Engineering: once the methodology was developed and applied to two companies, prototype CAE Systems to support Concurrent Engineering were created to automate the design process using an object oriented language called AML (Adaptive Modeling Language) by applying the concept of data driven applications (Molina et al., 1995). Data driven applications use two information models to support decision making in product development. These models are: Product and Manufacturing Model. The Product Model represents all the information required of a product through its life cycle. The information concerning the manufacturing capability and capacity of a firm's facility is captured in the Manufacturing Model. The use of these two models allows the designer to have readily access to all the information required to achieve concurrent design of products supported by design for $\mathrm{X}$ applications (Molina and Chemaly, 1996).

Two case studies has been completed in two companies. In the next sections detailed descriptions of the results achieved so far are presented.

\section{ASSESSMENT TOOL FOR CONCURRENT ENGINEERING}

The first phase in our research project was targeted to identify the areas of opportunity in Mexican Companies and how companies' product development environments are set. The Concurrent Engineering (CE) Assessment Tool created by Carter and Baker (1992) was selected to support our work in studying 12 Mexican companies. No specific criterion was chosen to select the companies for the study. The companies selected were: engineering companies for capital goods (2), glass manufacturers (2), automotive part's manufacturer (6), and house ware manufacturers (2).

The CE Assessment Tool allows the user to have an idea of what kinds of changes are necessary in a company to create a concurrent engineering environment. The CE Assessment Tools has four elements (Figure 1):

1. A questionnaire to assess the company's current product development environment

2. A Matrix to determine the CE methods the company needs in order to develop a give product successfully

3. A Dimension Map to determine where a company is and where it should be

4. A Priority Map to define the priorities to transform the current product development environment into a $\mathrm{CE}$ environment 


\begin{tabular}{|c|c|}
\hline \multicolumn{2}{|c|}{ PART FOUR - PRODUCT DEVELOPMENT } \\
\hline \multicolumn{2}{|c|}{ PART THREE - USER REQUIREMENTS } \\
\hline \multicolumn{2}{|c|}{ PART TWO-COMMUNICATION } \\
\hline \multicolumn{2}{|c|}{$\begin{array}{l}\text { The Quentionnaire } \\
\text { PART ONE - ORGANIZATION }\end{array}$} \\
\hline \multicolumn{2}{|c|}{ Team Integration } \\
\hline \multicolumn{2}{|c|}{$\begin{array}{l}\text { Individual enployees and teams } \\
\text { understand their roles and taks in } \\
\text { the context of the overall product } \\
\text { development process }\end{array}$} \\
\hline \multicolumn{2}{|c|}{$\begin{array}{l}\text { 1. Are the specifications and } \\
\text { priorities for the ascigned toks } \\
\text { undestood by the individuals? }\end{array}$} \\
\hline Answer: & $\mathbf{Y}$ \\
\hline
\end{tabular}

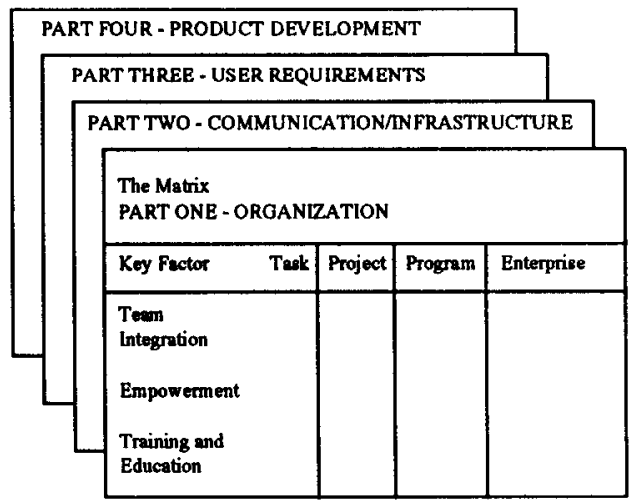

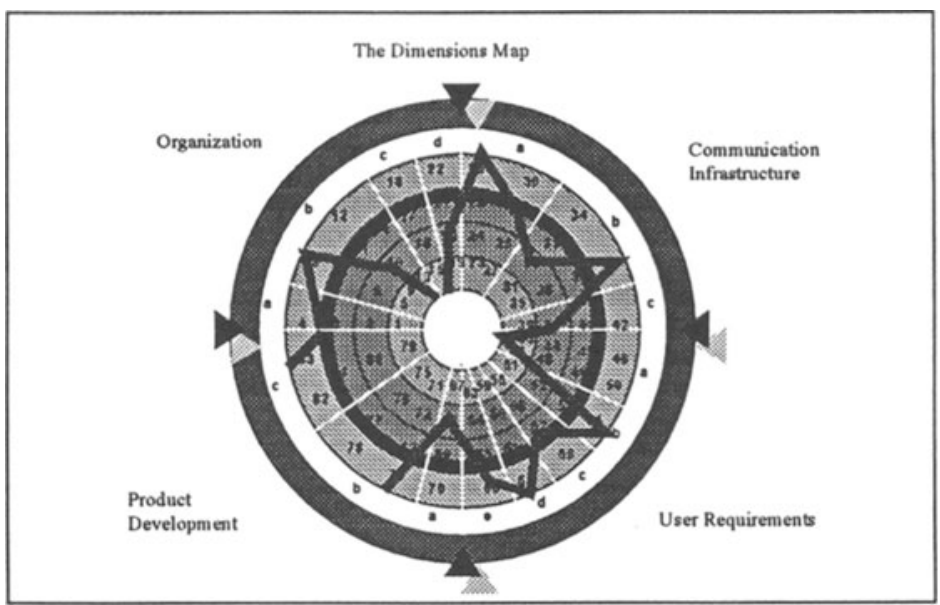

\begin{tabular}{|ll|c|c|}
\hline \multicolumn{3}{|c|}{ The Priority Roadmap } \\
\hline - Orgarization Dimension & Priority & Completed \\
\hline Key Factor & Action & 1 & When ? \\
$\begin{array}{ll}\text { Training and } \\
\text { Educstion }\end{array}$ & $\begin{array}{l}\text { Train in } \\
\text { New Tools }\end{array}$ & 1 & When ? \\
Product Data & $\begin{array}{l}\text { Standardize } \\
\text { Product Data }\end{array}$ & & \\
\hline
\end{tabular}

Figure 1 Concurrent Engineering Assessment Tool (Carter and Baker 1992). 


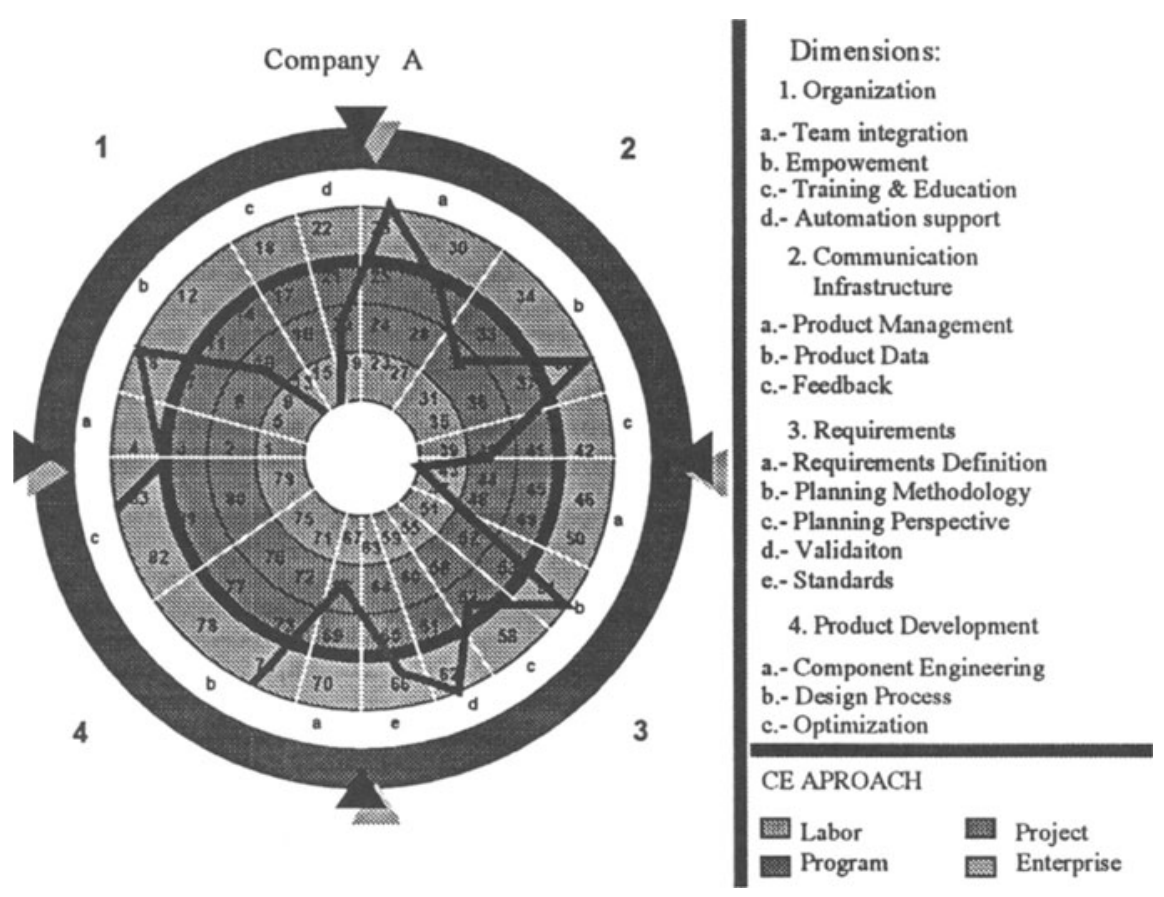

Figure 2 Concurrent Engineering Assessment of Company A

The dimensions of change are related to the organization, communication infrastructure, user requirements and product development. These changes can be made at different levels of teamwork: task, project, program and enterprise. Details of the methodology can be found in Carter and Baker (1992).

For each individual company an assessment was carried out (Figure 2). Key factors defined by the companies for the implementation of $\mathrm{CE}$ environments were tabulated. The following major issues were identified: the need to train/educate engineers and to support the automation of the design process, the lack of standardized product definitions and design for manufacture rules, and the necessity to introduce social-technical design concepts and cooperative design methods (Table 1).

\section{METHODOLOGY FOR RE-ENGINEERING THE DESIGN PROCESS}

A methodology has been developed in order to support companies in the introduction of Concurrent Engineering, especially to tackle the following issues: 
Table 1 Areas of Opportunity identified by Mexican Companies

\begin{tabular}{cc}
\hline $\begin{array}{c}\text { Key Factors Identified by } \\
\text { Companies }\end{array}$ & $\begin{array}{c}\text { Number of } \\
\text { Companies }\end{array}$ \\
\hline Training and Education & 9 \\
Automation Support & 9 \\
Product Data & 9 \\
Standards & 8 \\
Component Engineering & 8 \\
Design Process & 8 \\
Empowerment & 7 \\
Product Management & 6 \\
Planning Methodology & 6 \\
Requirements Definition & 6 \\
Feedback Protocol & 6 \\
Optimization Policy & 6 \\
Team Integration & 4 \\
Validation of Requirements & 4 \\
Planning Perspective & 1 \\
\end{tabular}

The necessity to introduce social-technical design concepts and cooperative design methods, and the need to train/educate engineers. This methodology has the following phases:

1. Diagnosis of Company's Product Value Chain (Suppliers-Products-Clients): evaluation of the characteristics of products being delivery to the client and being acquired from suppliers (material and components).

2. Analysis of Product Development Process Measures: definition and measure of key variables to evaluate the performance of the product development process, for example: product development lead time, extent of co-engineering, number of people in product development, etc.

3. Identification of Product Development Core Processes: detail description of processes within product development that are key to the success of product designs, for example: product research, product engineering and design, coengineering, etc. These processes are modeled using IDEF0 (ICAM, 1980).

4. Identification of Product Design Core Competencies: definition, evaluation and allocation of technological capabilities of humans and technical resources necessary to achieve Concurrent Engineering. The concept of core competencies from Prahalad and Hamel (1990) is used to establish the criteria for their identification, acquisition, building and deployment.

5. Strategic Planning of Technology: definition of the situation "as-is" and situation "to-be" in the product development process, and establishment of the 
transition plans to achieve Concurrent Engineering. The strategic planning methodology is based on the Purdue Reference Architecture (Williams, 1993).

6. Implementation of Technology Integration Plans to achieve Concurrent Engineering.

The above methodology has been applied to two of the companies that participated in the assessment study: Automotive Parts Die Design Company and Glass Manufacturing Company.

\section{COMPUTER AIDED ENGINEERING SYSTEMS FOR CONCURRENT ENGINEERING}

Prototype systems, for two company's re-engineered product development process, are being developed to explore how to overcome the lack of standardized product definitions and design for manufacture rules, and to support the automation of the design process. The following tasks are involved in these projects:

1. Modeling the Product Development Process using IDEF0 (ICAM, 1980).

2. Definition/Documentation of Product and Manufacturing Models using EXPRESS (ISO CD $10303-11$ )

3. Implementation of Product and Manufacturing Models using the object oriented environment for Knowledge Based Engineering AML - Adaptive Modeling Language (Molina and Chemaly, 1996).

4. Automation of the design process by implementing Design for Manufacture applications using AML

The idea behind this methodology is based on the fact that Concurrent Engineering can be effectively supported by computer technologies (e.g. CAE systems) if reliable and high quality data is provided to the engineers at all the stages of the product development. The methodologies to develop Product and Manufacturing Models can be found in Molina and Chemaly (1996). The work related to the implementation of the prototype systems for the two companies is at different stages of development. The following subsections describe the results achieved so far.

\subsection{Concurrent Die Design for Automotive Parts}

The objective of this project is to automate the design of dies for internal and external automotive parts. The analysis, standardization and documentation of the design process have been completed and the construction of the Product Model is being implemented in AML. Important comments on this case study are:

- There was a need to redefine the design process and create new structures for the design teams and incorporate product management techniques.

- The information required to develop the dies was not structured causing a lot of errors in the communication of product data between the designer, technical 
sketcher and process designer. Therefore checklists were introduced to control the exchange of drawings and technical data.

- The Product Model being constructed incorporates the following technical data: die features, die components, and manufacturing technology data.

- An integrated system is being developed based on AML to allow the automated generation of die' drawings, NC code and manufacturing process data.

\subsection{Integrated Environment for Glass Products}

The prototype is complete for a family of water glass products. The system is able to design lemonade glasses and verifies the manufacturability of the product being designed. It can also produce the process plan for their production in order to estimate production time and sales cost. Finally, the system can automatically generate the drawing for tooling for the Machine Drive Press glass process. Figure 3 shows different aspects of the prototype system. Some key technical aspects in the development of this prototype were:

- Knowledge elicitation is the hardest work in the development of automated systems. Experts are always busy and are reluctant to share their knowledge.

- The core knowledge of the glass design is in the tool system, therefore the Product Model has to be built around this knowledge.

- Not all the DFM rules can be captured, but the benefit of building such a system is that new rules can easily be incorporated or old rules updated.

\section{CONCLUSIONS}

Global competition has forced Mexican Industry to look for new concepts in order to become competitive and being able to survive. In this paper first attempts to support Mexican companies in this survival endeavor have been presented. GIINCIVI of CSIM-ITESM has defined a three phase research project in order to introduce Concurrent Engineering (CE) in Mexican Companies. The results of the first phase are the identification of key factors for a successful introduction of CE. This study allowed GI-INCIVI to define a methodology to help companies to implement $\mathrm{CE}$ by introducing new social-technical design concepts and cooperative design methods. It also helped in the identification of major topics for the development of CE training programs for company's engineers. Finally, prototype systems were developed to have standardized product definitions, improve the level of automation and apply proven design for manufacture rules in the design process. Two case study has been briefly described: Automotive Part Die Design and Design of Glasses for Machine Drive Press process. 

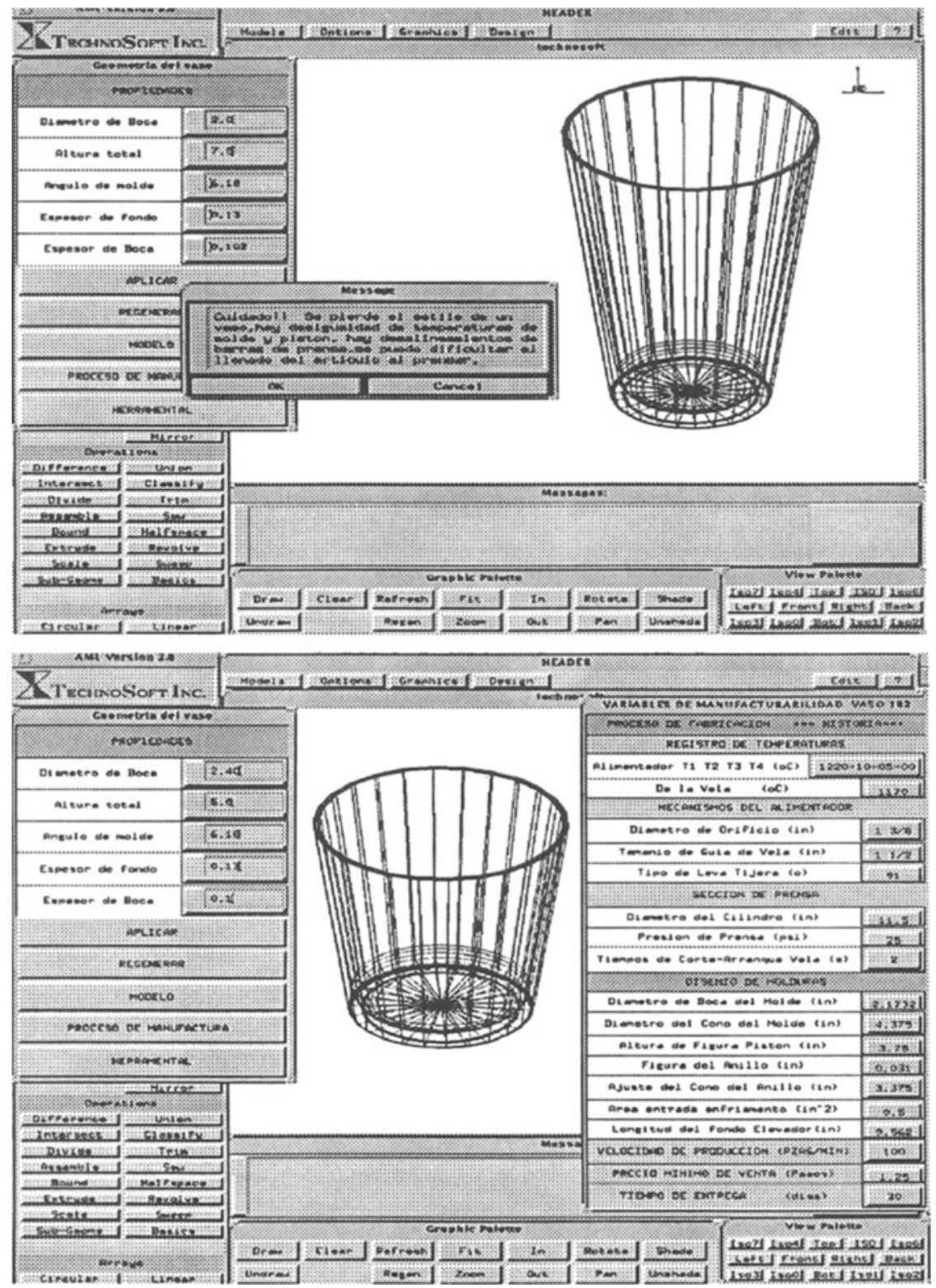

Figure 3 Prototype System of the Integrated Development Environment of Glass Products: a) DFM applications to advise designer in defining manufacturable glass dimensions b) Automatic generation of production plans to advise on production variables, production time and sales cost. 


\section{ACKNOWLEDGEMENTS}

The authors want to acknowledge the following members of the GI-INCIVI who helped to developed the prototype systems: Luis Alberto Rodriguez, Juan de Dios Rodriguez, Jose Luis Acosta, Julio Jaime Scheib and Mario de Diego.

\section{REFERENCES}

Bernus, P. and Nemes, L. (1994) A Framework to Define a Generic Enterprise Reference Architecture and Methodology. Draft proposal, IFAC/FIP Task Force on Architectures for Enterprise Integration, Eight Workshop Meeting, Vienna, Austria, June 11-12.

Carter D. and Baker B. (1992) Concurrent Engineering: The product Development Environment for the 1990s. Addison-Wesley Publishing. USA.

Gomez E., and Molina A. (1996) Concurrent Engineering in Mexican Companies, Revista Transferencia, Año 9, Número 35, Julio de 1996, pp. 23-25, in Spanish.

Gomez E. (1996) Methodology for the Creation of Product Models, Master Thesis, Manufacturing Engineering, December 1996, ITESM., in Spanish.

Guerra D. (1996) Methodology for the elicitation and representation of Design for Manufacturing Rules in a Family of Machine Drive Press Glasses and it's Impact in the Development of New Product, Master Thesis, Manufacturing Engineering, December 1996, ITESM., in Spanish.

ICAM (1980) Architects' Manual ICAM Definition Method (IDEF0), DR-80ATPCol.

ISO CD $10303-11$, Industrial automation systems and integration - Product data representation and exchange - Part 11: Description methods: The EXPRESS language reference manual.

Molina, A. et al. (1995) A Review of Computer Aided Simultaneous Engineering Systems, Research in Engineering Design, 7:38-63.

Molina A., and Chemaly A. (1996) Information Models to Support Computer Aided Simultaneous Engineering, Proceedings of the TMCE'96 Conference, Budapest, Hungary, June 29-31, pp. 231-42.

Molina A. (1996) Report on Enterprise Integration Research at CSIM-ITESM, Presented at the 14th Workshop Meeting of the Task Force on Architectures for Enterprise Integration, San Francisco California, July 2, 1996.

Prahalad C.K. and Hamel G. (1990) Harvard Business Review, May-June, pp. 79 91.

Williams, T.J. et al. (1993) Architectures for Integrating Manufacturing Activities and Enterprises, in $\mathrm{H}$. Yoshikawa and J. Goossenaerts (eds.), Information Infrastructure Systems for Manufacturing, Proceedings, JSPE/IFIP TC5/WG5.3 Workshop on the Design of Information Infrastructure Systems for Manufacturing, DIISM'93, Tokyo, 8-10 November, 1993, North-Holland, pp. 316. 


\section{BIOGRAPHY}

Dr. Arturo Molina is an Associate Professor in the Integrated Manufacturing System Center at Monterrey Institute of Technology (ITESM), Campus Monterrey, Mexico. He received his M.Sc. degree in Computer Science from ITESM, Campus Monterrey in December 1990, his University Doctor degree in Mechanical Engineering at the Technical University of Budapest in November 1992, and Phd in Manufacturing Engineering from Loughborough University of Technology in 1995 His current research interests include information systems support for concurrent engineering, information modeling, enterprise modeling and integration.

Enrique Gomez is associate consultant of A.T.Kearney. He received his M. Sc. degree in Manufacturing Engineering from ITESM Campus Monterrey in December 1997 and B. Sc in Industrial Engineering at ITSON, Sonora, Mexico.

David Guerra is an employee of VITROCRISA SA de CV, company from the VITRO Group in Monterrey, Mexico. He is working in the product development group of the Technology Department. He received his M.Sc. in Manufacturing Engineering in December 1996 and M.Sc. in Mechanical Engineering in May 1992 from ITESM Campus Monterrey. 